\title{
STUDY ON DESIGN AND STATIC ANALYSIS OF PISTON HEAD
}

\author{
Amitanand B Suralikerimath ${ }^{1}$, Yallanagouda I Ninganagoudar ${ }^{2}$, C.M Veerendrakumar ${ }^{3}$ \\ ${ }^{1}$ Student, Department of Mechanical Engineering, Basaveshwar Engineering College, Karnataka, India \\ ${ }^{2}$ Student, Department of Mechanical Engineering, Basaveshwar Engineering College, Karnataka, India \\ ${ }^{3}$ Associate Professor, Department of Automobile Engineering, Basaveshwar Engineering College, Karnataka, India
}

\begin{abstract}
I.C engine piston is one of the most important and complex component in the engine. It is also sometimes referred as the heart of engine. It is widely used mainly in automotive and mechanical fields hence, a detailed study on its static behavior is important. This paper emphasizes on the static analysis of the piston head of a 4-stroke I.C engine. In the present work piston head is designed using CATIAV5R20 and this model is analyzed in ANSYS 14.5 and a study on its static behavior is performed. Aluminum alloy has been selected as piston material for structural analysis. The theoretical stress values obtained is compared with the stress values obtained after the analysis in ANSYS 14.5.
\end{abstract}

Keywords: Piston Head, I.C Engine, CATIA V5R20, ANSYS 14.5, Static Analysis.

\section{INTRODUCTION}

Piston is one of the most important components of engine. It is a part in motion which is present in cylinder. In the engine the expansion of gas occurs in cylinder up to crankshaft through connecting rod. The piston lasts this gas pressure and inertial forces at work and this may lead to crack formation and piston wear. The study reports show that stress concentration is highest at upper portion and this is one of the main reasons for crack formation and wear. This paper describes stress distribution on piston head of an IC engine by using finite element method. It is achieved by CAD and CAE softwares. Our main purpose is to study the static behavior of piston head and analyze the stress distribution. By using CATIAV5R20 model of the piston head is developed. Stress analysis is carried out by using ANSYS 14.5. The results obtained from ANSYS 14.5 are compared with the calculated theoretical stress values.

A lot of research has been undertaken in optimizing the piston head. Ashwani Kumar et al [1] the main objective of this research work is to investigate and analyze the stress distribution of piston at actual engine condition. Analysis of the stress distribution was carried out on different parts of the piston for determining the stresses due to the gas pressure. S N Kurbet et al [2] studies related to the working of the engine parts, the piston is considered as main source of the vibration and noise the emphasis is on the piston vibration and to find out the various methods to predict mechanical noise produced by the primary and secondary motion of the engine part.

\section{MATERIAL PROPERTIES}

Aluminium alloy is selected for the design and analysis of the piston head. Properties of the aluminium alloy are mentioned below.

Density - $2770\left(\mathrm{Kg} / \mathrm{m}^{3}\right)$

Poisson Ratio - 0.33

Young Modulus - 7.1×10 $0^{10}(\mathrm{~Pa})$
Tensile Ultimate Strength $-3.1 \times 10^{8}(\mathrm{~Pa})$

Tensile Yield Strength $-2.8 \times 10^{8}(\mathrm{~Pa})$

Compressive Yield strength $-2.8 \times 10^{8}(\mathrm{~Pa})$ [3]

\section{CALCULATIONS}

Bore diameter $=100 \mathrm{~mm}(\mathrm{D})$, Stroke length $=120 \mathrm{~mm}(\mathrm{~L})$, Gas pressure $=5 \mathrm{MPa}, \mathrm{BMEP}=0.5 \mathrm{MPa}$, Fuel consumed $=$ $0.15(\mathrm{Kg}) /$ Brake Power $(W)$, Speed $=2200 \mathrm{rpm}(\mathrm{N})$ [4]

Step 1:

Brake power (BP) .in $K W$

$\mathrm{BP}=\mathrm{PLAN} /(1000 \times 60) K W$

Where, $\mathrm{P}=\mathrm{BEMP}=0.5 \mathrm{MPa}$

$\mathrm{L}=$ Stroke length $m$

A $=$ Cross Section area $m^{2}$

$\mathrm{N}=$ Speed $r p m$

$\mathrm{BP}=0.5 \times 120 \times 100^{2} \times 2200 \times \pi /(1000 \times 4 \times 60)$

$$
=17.275 \mathrm{KW}
$$

Step 2:

Thickness of the piston head by considering the heat dissipation

$\mathrm{t}_{1}=\mathrm{D}^{2} \mathrm{q} /\left[1600 \times \mathrm{K} \times\left(\mathrm{T}_{\mathrm{c}}-\mathrm{T}_{\mathrm{e}}\right)\right] \mathrm{mm}$

Where, $\mathrm{t}_{1}=$ thickness of piston head $\mathrm{mm}$

$\mathrm{q}=$ Heat flow $\mathrm{J} / s-m^{2}$

$\mathrm{k}=$ Heat conductivity $W-\mathrm{mm} /\left(\mathrm{m}^{2}-{ }^{0} \mathrm{c}\right)$

$\mathrm{T}_{\mathrm{c}}-\mathrm{T}_{\mathrm{e}}=$ difference between the Temperature at centre and edges $=222 \mathrm{~K}$

$\mathrm{q}=\mathrm{K}_{1} \times \mathrm{C} \times \mathrm{W} \times \mathrm{BP} /(\mathrm{A}) \mathrm{J} / \mathrm{s}-\mathrm{m}^{2}$

Where, $\mathrm{K}_{1}=$ Constant which represents the amount of heat soaked by piston. 


$$
\begin{gathered}
\text { C = Calorific value of the fuel }=42000 \mathrm{KJ} / \mathrm{Kg} \\
\mathrm{W}=\text { fuel consumed }=0.15 \mathrm{Kg}-\mathrm{hr} / \mathrm{KW} \\
\mathrm{A}=\pi \mathrm{d}^{2} /(4)=\pi \times(0.1)^{2} /(4)=7.85 \times 10^{-3} \mathrm{~m}^{2} \\
\mathrm{q}=0.05 \times(42000 \times 1000) \times(0.15 / 3600) \times 17.278 /\left(7.854 \times 10^{-}\right. \\
\left.{ }^{3}\right)=192491 \mathrm{~J} / \mathrm{s}-\mathrm{m}^{2} \\
\mathrm{t}_{1}=100^{2} \times 192491 /(1600 \times 460 \times 222)=11.78 \mathrm{~mm}
\end{gathered}
$$

\section{Step 3:}

The thickness of the piston head using Grashof's formula $\mathrm{t}_{1}=0.43 \mathrm{D} \sqrt{ }\left(\mathrm{P} / \sigma_{\mathrm{t}}\right) \mathrm{mm}$

$\mathrm{P}=$ Gas pressure in $\mathrm{MPa}$

$\sigma_{\mathrm{t}}=$ Allowable tensile stress $M P a$

$=280 / 2.25$

$=124.4 \mathrm{MPa}$

$\mathrm{D}=100 \mathrm{~mm}$

$=0.43 \times 100 \sqrt{ }(5 / 124)$

$=8.7 \mathrm{~mm}=9 \mathrm{~mm}$

Adopt the greater value of the $t_{1}$ i.e. $t_{1}=11.78 \mathrm{~mm}$

Step 4:

Piston ring properties

The radial thickness of the ring $t_{r}$ $\mathrm{t}_{\mathrm{r}}=\mathrm{D} \times \sqrt{ }\left(3 \mathrm{P}_{\mathrm{r}} / \sigma_{\mathrm{t}}\right) m m$

Where, $\mathrm{P}_{\mathrm{r}}$ is pressure exerted by fuel on cylinder wall in $\mathrm{N} / \mathrm{mm}^{2}$. Its value varies from 0.025 to $0.042 \mathrm{~N} / \mathrm{mm}^{2}$

$$
=100 \times \sqrt{ }(3 \times 0.042 / 124)
$$$$
=3.187 \mathrm{~mm}
$$

The distance from top to first groove $t_{\mathrm{g}}$

$$
\begin{aligned}
\mathrm{t}_{\mathrm{g}} & =1 \mathrm{t}_{1} \text { to } 1.2 \mathrm{t}_{1} \\
& =1.2 \times 11.78 \\
& =14 \mathrm{~mm}
\end{aligned}
$$

Number of rings $i$

$$
\begin{aligned}
\mathrm{i} & =100 /(10 \times \mathrm{h}) \\
& =100 /(10 \times 2.22)=4 \text { rings }
\end{aligned}
$$

The maximum thickness of piston barrel $\mathrm{t}_{3}$ $\mathrm{t}_{3}=0.03 \mathrm{D}+\mathrm{b}+4.5 \mathrm{~mm}$

Where, $\mathrm{b}$ is the depth of the ring grooves in $\mathrm{mm}$

$$
\begin{aligned}
\mathrm{b} & =\mathrm{t}_{\mathrm{r}}+0.4 \mathrm{~mm} \\
& =3.187+0.4 \\
& =3.587 \mathrm{~mm} \\
\mathrm{t}_{3} & =0.03 \times 100+3.587+4.5 \\
& =11.08 \mathrm{~mm}
\end{aligned}
$$

Thickness of the wall towards the open end of the piston $t_{4}$

$$
\begin{aligned}
\mathrm{t}_{4} & =0.25 \mathrm{t}_{3} \text { to } 0.35 \mathrm{t}_{3} \\
& =0.25 \times 11.08 \\
& =3.32 \mathrm{~mm}
\end{aligned}
$$

Diameter of the piston pin $\mathrm{d}=\pi \times \mathrm{D}^{2} \times \mathrm{P}_{\max } /\left(4 \times \mathrm{l}_{1} \times \mathrm{P}_{\mathrm{b}}\right)$

Where $\mathrm{l}_{1}=1.5 \mathrm{~d}$

$\mathrm{P}_{\mathrm{b}}$ is bearing pressure in $M P a$ which is 15.7 for aluminium alloys.

$$
\begin{aligned}
& =\pi \times 100^{2} \times 5 /[4 \times(1.5 \mathrm{~d}) \times 15.7] \\
\mathrm{d} & =40.83 \mathrm{~mm}
\end{aligned}
$$

\section{Step 5:}

Theoretical Stress Calculation $\sigma_{\mathrm{b}}=\mathrm{M}_{\mathrm{b}} / \mathrm{W}_{\mathrm{b}} M P a$

Where $\mathrm{M}_{\mathrm{b}}$ is the bending moment and $\mathrm{W}_{\mathrm{b}}$ is the moment of resistance to the bending

$\mathrm{M}_{\mathrm{b}}=1 / 3 \times \mathrm{P}_{\max } \times \mathrm{r}_{\mathrm{i}}^{3} M N m$

$\mathrm{P}_{\max }=$ Maximum gas pressure in $M P a$. This value varies between 2-5 MPa in case of aluminium alloys. [3]

$\mathrm{r}_{\mathrm{i}}=$ crown inner radius $m$

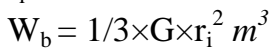

$\mathrm{G}=$ Thickness of piston crown $m$

$\mathrm{r}_{\mathrm{i}}=\left[\mathrm{D} / 2-\left(\mathrm{s}+\mathrm{t}_{\mathrm{r}}+\mathrm{dt}\right)\right] m$

$\mathrm{dt}=$ Radial clearance between piston rings and channel $m$

$\mathrm{s}=$ Thickness of the sealing part $m$

$=[0.1 / 2-(0.005+0.0008+0.0031)]=0.0413 \mathrm{~m}$

$\mathrm{M}_{\mathrm{b}}=1 / 3 \times 5 \times 0.0413^{3}$

$=1.174 \times 10^{-4} \mathrm{MNm}$

$\mathrm{G}=(0.08$ to 0.1$) \mathrm{D} m$

$$
=0.091 \times 100
$$

$$
=9.1 \mathrm{~mm}
$$

$\mathrm{W}_{\mathrm{b}}=1 / 3 \times 0.0413 \times 0.0091^{2}$

$$
=1.14 \times 10^{-6} \mathrm{~m}^{3}
$$

$\sigma_{\mathrm{b}}=1.17 \times 10^{-4} / 1.14 \times 10^{-6}$

$$
=103 \mathrm{MPa}
$$

The theoretical stress value obtained is less than the allowable stress $(103<124 \mathrm{MPa})$. Hence the design is safe.

\section{MODELLING IN CATIA V5R20}

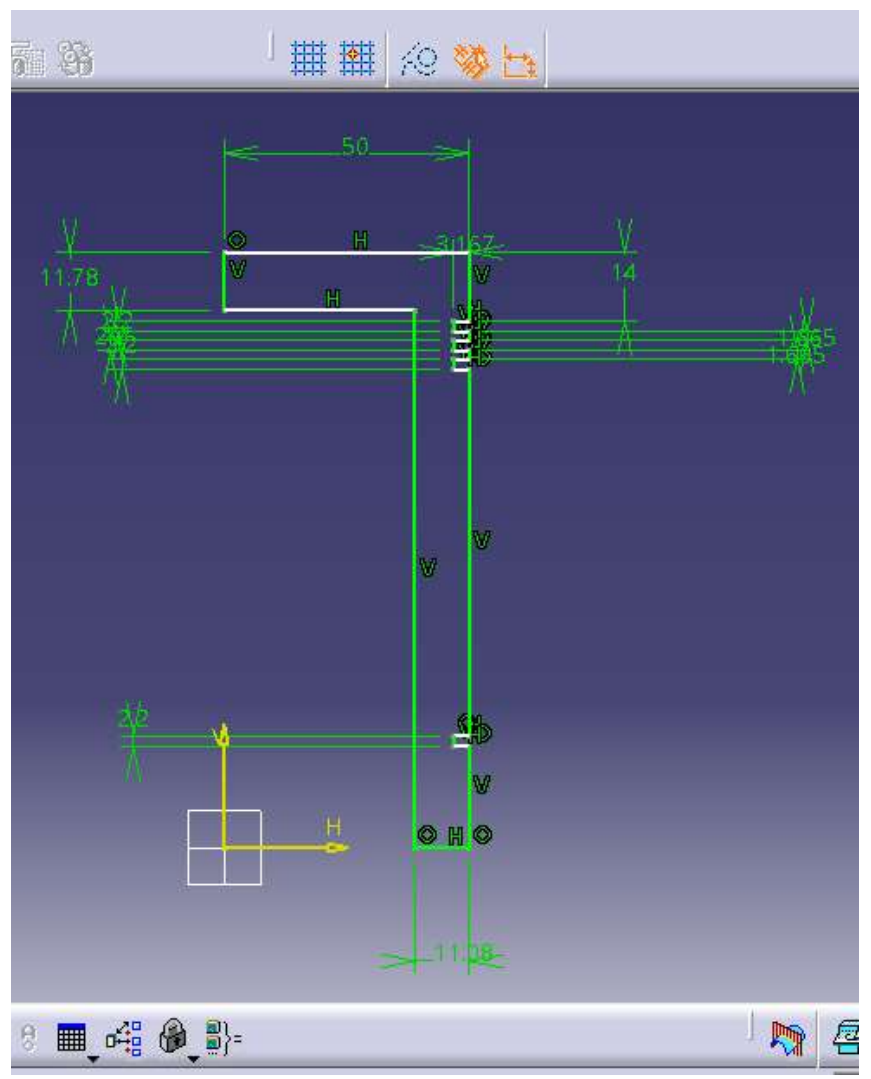

Fig. 1 Sketching in CATIA V5R20 

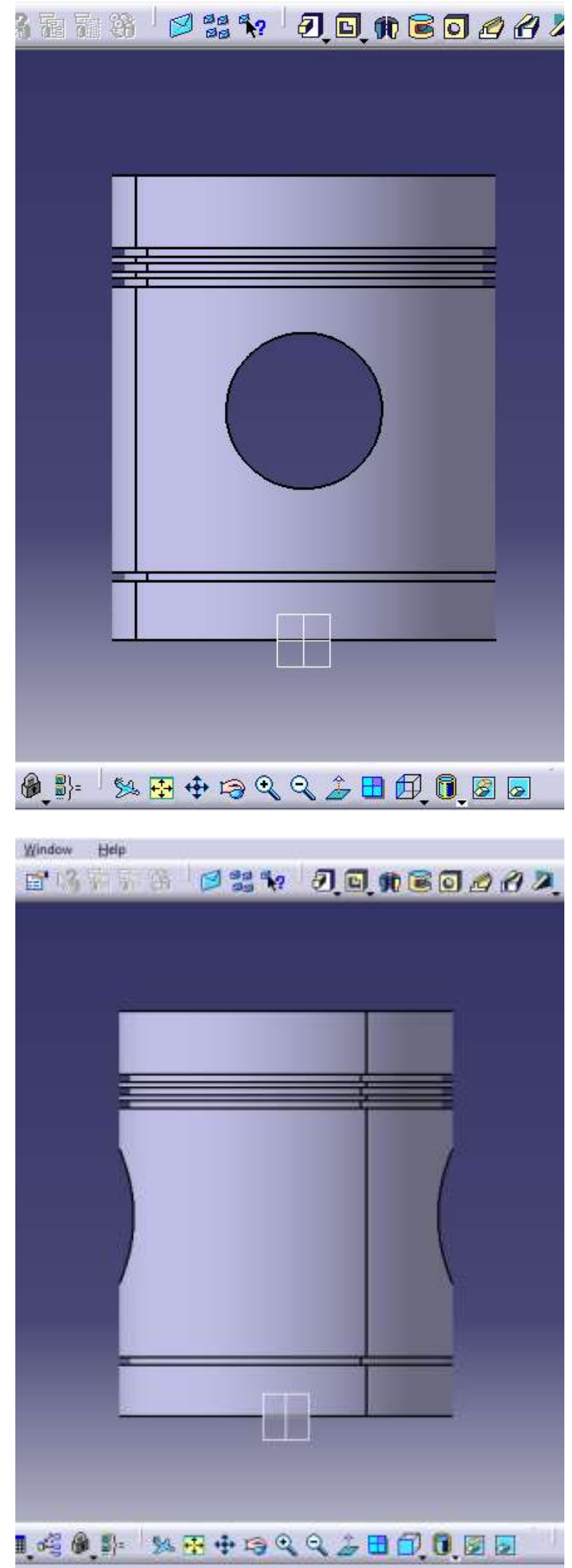

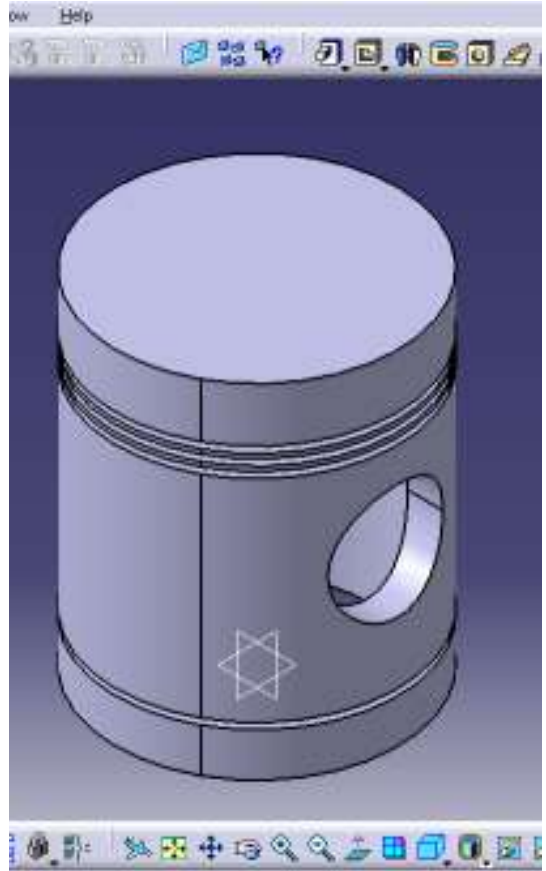

Fig.2 Piston head modeled in CATIA V5R20 based on above calculations

\section{ANALYSIS IN ANSYS 14.5}

After designing the model in CATIA V5R20 the model is converted to STP file and imported to ANSYS 14.5. Then analysis is carried out accordingly in following steps.

\subsection{Defining the Material}

Aluminum alloy is chosen and applied to the imported model. All the material properties of aluminum alloy are predefined by the software.

\subsection{Meshing the Model}

In order to analyze the model by FEM meshing of the model must be done. The element size and shape of the mesh are defined. Here we have considered the element size as 15 and shape of the mesh as triangular.

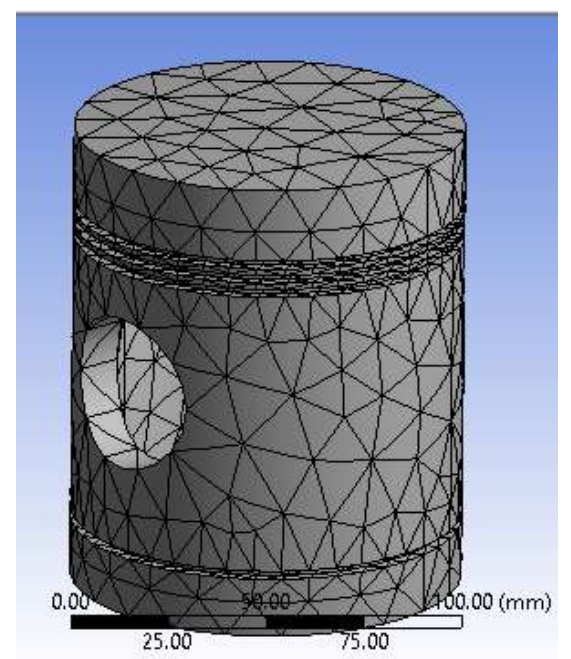

Fig.3 Meshing of the model in ANSYS 14.5 


\subsection{Structural Analysis}

\subsubsection{Restraining the Model at Piston Pin Holes}

Piston pin holes are considered as fixed support. Hence frictionless support is applied and it is restrained at its holes.

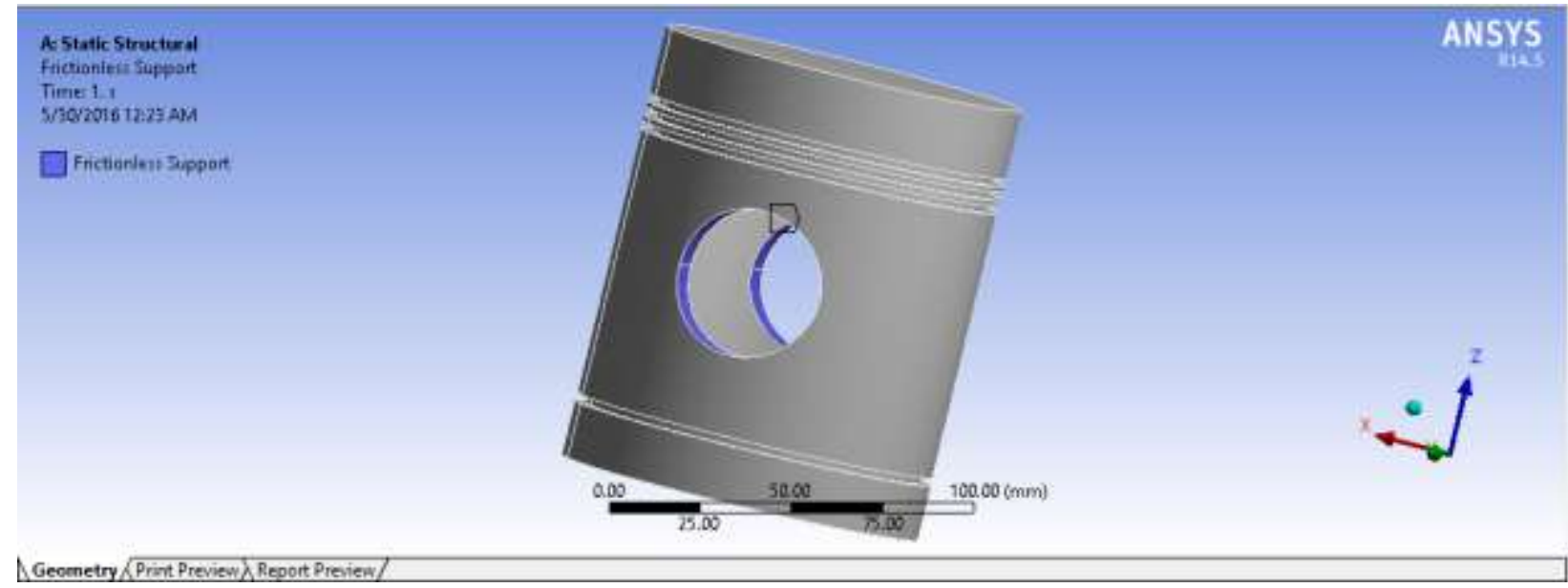

Fig.4 Restraining the model at piston pin holes

\subsubsection{Applying Pressure on Top Surface}

For static structural analysis the pressure of magnitude 5 $M P a$ is applied on the top surface of the piston head. The gas combustion pressure for aluminum alloy is $5 \mathrm{MPa}$.

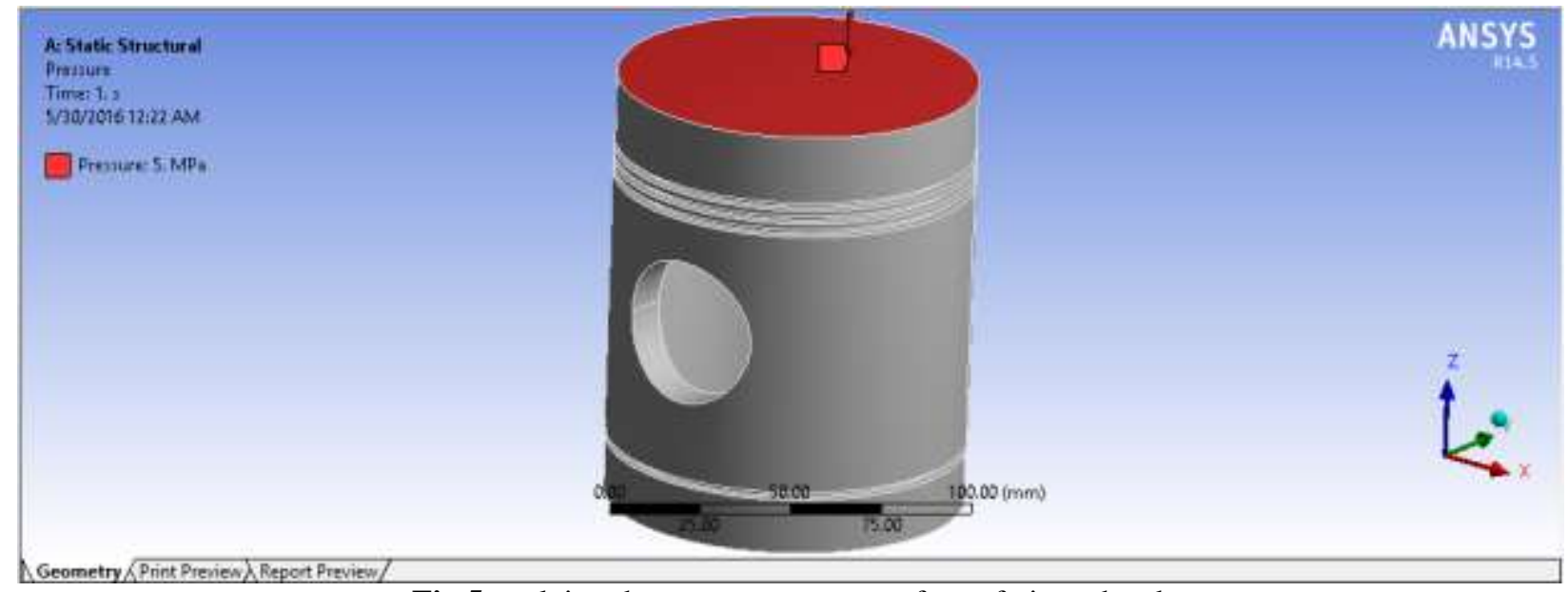

Fig.5 applying the pressure on top surface of piston head

\section{RESULTS}

The model is solved after applying the pressure and results are obtained for Von-Mises stress and structural deformation which are shown below. The value of structural deformation obtained is $0.7314 \mathrm{~mm}$ and stress value obtained is 103.32 MPa.

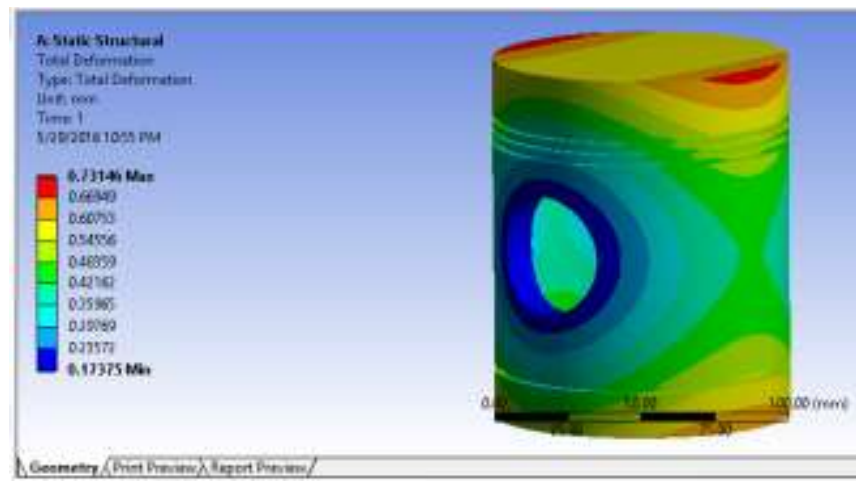

Fig.6 Results obtained for Structural deformation of piston head 


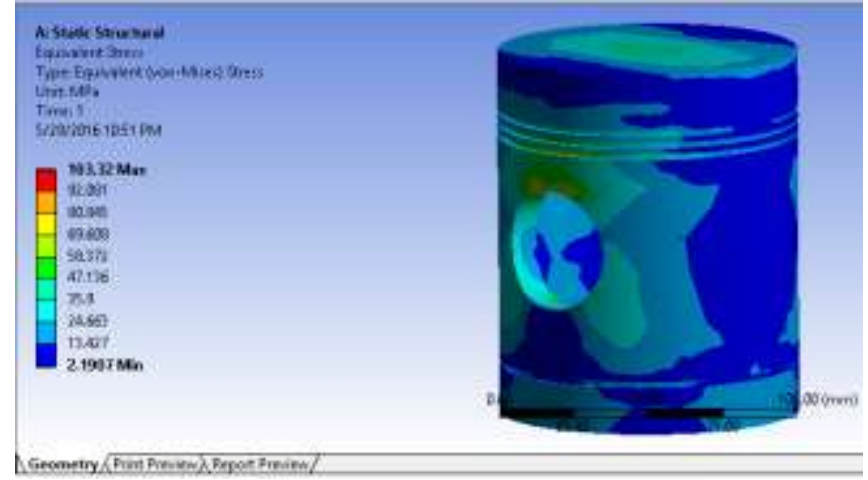

Fig.7 Results obtained for stress in piston head

\section{CONCLUSION}

The following conclusions can be drawn after the analysis

- The theoretical stress value obtained is very close to the stress values obtained after analysis of the model in ANSYS 14.5.

- The structural deformation is least at the piston pin holes and maximum at the top surface.

- The stress concentration is highest at piston pin holes.

\section{RECOMMENDATIONS}

- The analysis can be further carried out for thermal analysis from which we can compute the thermal stress induced in various portions of piston head.

- Dynamic and vibrational analysis also can be carried out to study dynamic behavior.

- CFD analysis can be performed in order to compute the fluid forces, heat flow and impact of fluid pressure on piston.

\section{REFERENCES}

[1]. Ashwani Kumar et al, Thermo-mechanical and vibration analysis of the I.C Engine piston made of Sic reinforced ZrB2 composite using Finite Element Method (ANSYS).

[2]. 'S.N Kubet' et al, "Thermal analysis of piston for the influence on secondary motion." International Journal of Engineering Research and applications, Vol. 3, issue 3.

[3]. Internal Combustion Handbook SAE International.

[4]. Design Data handbook for mechanical engineers, $\mathrm{K}$ Mahadevan and K Balaveerareddy.

\section{BIOGRAPHIES}

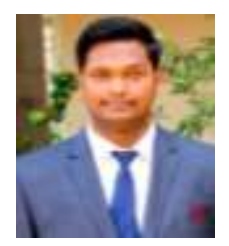

Amitanand B Suralikerimath is the first author studying in the final year of Bachelor of Engineering in Basaveshwar Engineering College, Bagalkot. His areas of interest are Solid Mechanics, Applied Mechanics and Machine Design.

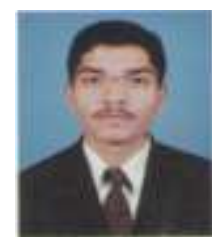

Yallanagouda I Ninganagoudar is the second author studying in the final year of Bachelor of Engineering in Basaveshwar Engineering College, Bagalkot. His areas of interest are Strength of Materials and Machine Design.

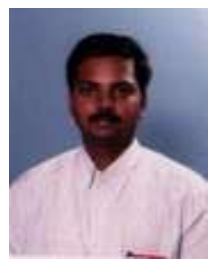

Dr. C.M Veerendrakumar is the correspondence author and is currently working as Associate Professor in Department of Automobile Engineering, Basaveshwar Engineering College. He completed his B.E in Automobile Engineering and MTech in Machine Design from K.U.D Dharwad and V.T.U Belgaum respectively. He obtained his $\mathrm{PhD}$ from V.T.U Belgaum. His areas of research are Design, synthesize and analysis of Mechanisms. 